\title{
Review on Compressed Hydrogen as Contemporary Renewable Energy Resource
}

\author{
Džoljić Jovana ${ }^{1, *}$, Stevović Svetlana ${ }^{2}$ \\ ${ }^{1}$ College of Applied Professional Studies Vranje, Filipa Filipovića 20, Serbia \\ ${ }^{2}$ Faculty of Ecology and Environmental Protection, University Union Nikola Tesla, Serbia
}

Copyright $\bigcirc 2017$ by authors, all rights reserved. Authors agree that this article remains permanently open access under the terms of the Creative Commons Attribution License 4.0 International License

\begin{abstract}
Economic and ecological aspects of hydrogen use and analyzes of its characteristics for possible use as an alternative, renewable resource are presented in this work together with methods of its production, compression and transport, including experimental methodology of nanocapillaries. Due to the high price of its production technology, use of compressed hydrogen is limited nowadays. Numerous researches identify the most efficient ways of hydrogen production and storage that can be economically highly competitive at market. New advanced technologies of hydrogen production, together with extent of the photo-biological, photo-electrical and thermo-chemical use, could be used but, for now, are not neither acceptable nor have economic benefits. At the same time, innovation of classical methods of hydrogen storage highlight that most probably metal hydrides, respectively the newest technology of carbonate nanocapillaries and glassy microspheres, could be used. As one of the major challenges was identified establishment of hydrogen in the transport field, as a replacement for a fuel in the internal combustion engines, respectively as the fuel for driven fuel cells. Price of hydrogen limits the wider use of the fuel cell technology even thought is developed enough to be introduced in the commercial vehicles.
\end{abstract}

Keywords Compressed Hydrogen, Renewable Energy Resource, Alternative Resource

\section{Introduction}

In the numerous studies of environmental impacts have been showed the high degree of pollution and environmental degradation, which contributes to global warming $[13,14]$. Growing concern of overall exploitation of natural resources leads to necessarily orientation towards renewable sources of energy. Due to the World energetics crisis all countries develop plans and programs for energy use [16], but usually without consideration its own energy potentials. Together with growing consumption of oil, natural gas and coal, the main energy sources and raw materials in the chemical industry [9], could be expected expansion and rapid development and technological innovations that should improve use of traditional sources and use of a new and / or alternative energy sources (solar, geothermal, wind and sea power as well as oil sand or oil shale, biomass and nuclear energy). Produced energy should be transported and stored in the proper way for the future use. Considering the requirements for storage and transport of considerable amount of energy, nowadays, should be pointed out that still they don't fulfill all safety requirements. From the all previously mentioned sources, non-fossil types like nuclear power fission type have the leading role in the overall energy consumption with $19 \%$ at the beginning of XX century.

Rapid decrement of natural resources and enormous pollution present the biggest problems related to the fossil fuels use $[15,16]$. It is considered that up to the 2020 year need for energy consumption will increase for $75 \%$, and decrement in the oil production is expected from the next year. As the most attractive solution, for now, was identified use of solar energy and hydrogen, wind power and biomass. Theoretical ideas are already developed, but decades of the work and high investment are needed.

Numerous studies showed hydrogen as renewable, clean and effective energy source, but still its market price currently is too high for commercial use. Despite very good $\mathrm{CO} 2$ balances of hydrogen from renewable energy sources, the use of hydrogen in cars will not become competitive before 2050 due to high capital costs [1]. After large investment in the processing plants, improving hydrogen stations network and development of new models of compressed hydrogen transport and storage [10], give it leading position among the alternative energy sources.

Hydrogen storage technology must be significantly advanced in performance and cost effectiveness if the hydrogen-based transportation system is going to be established. Hydrogen provides more energy than either 
gasoline or natural gas can on a weight basis. Only when the weight, volume, and round-trip energy costs of the entire fuel storage system and charging/discharging cycle is considered, hydrogen's drawbacks become apparent. New approaches enabling more compact, lightweight, and energy efficient hydrogen storage are required in order for the wide-spread use of hydrogen powered vehicles to become a reality [6]. Increasing attention of the car giant companies encourages researchers and all interested parts for using hydrogen as the fuel. For example, the BMW became especially interested after recently increment of oil price [17]. Also, big companies like Royal Dutch/She already gave support for hydrogen use.

One of the most important characteristics of use hydrogen as a fuel is, for sure completely harmlessness on the environment. Energy produced in this way can be used as a fuel for the cars, all kinds of devices, as well as for city lightening and heating with only demineralized water as a by-product. Modern technology offers simple solution of transmission chemical related energy from the fuel to electrical energy, and in the case of the fuel cells hydrogen is needed power source.

Development and deployment of innovative hydrogen and fuel cell technologies with the ultimate goals could lead to the decrement of U.S. dependence on oil, reduced carbon emissions enabling clean, reliable power generation [12].

\section{Materials}

Hydrogen is the most common element, chemically very reactive and constitutes around $93 \%$ of all known atoms, or $3 / 4$ of total mass of space. As free element it appears only in small concentrations. It has specific position in the Periodic Table of Elements, according to its electron configuration it belongs to the alkaline metals, but regarding its characteristics and number of needed electrons can be considered as a halogen (with less reactivity). It is the only fuel gas that does not contain any carbon atoms [18]. Physical properties and main characteristics are presented in the Figure 1. and Table 1.

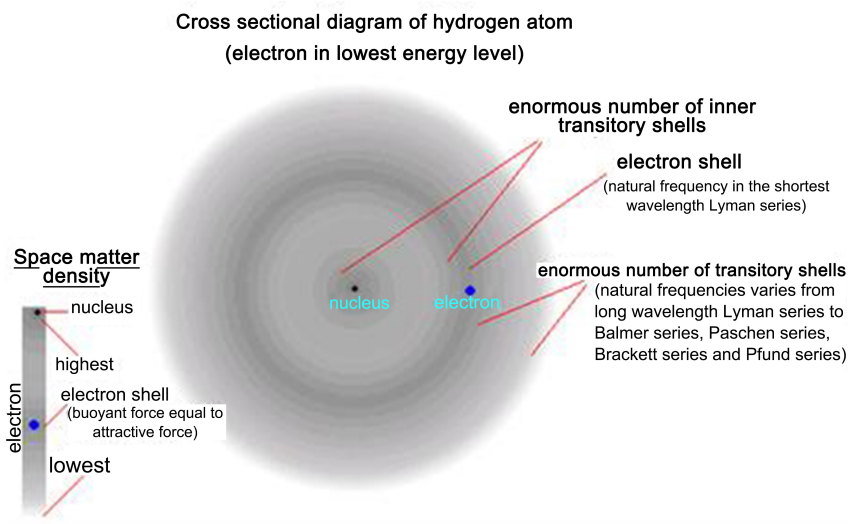

Figure 1. Cross sectional diagram of hydrogen atom [19]
Table 1. Physical properties and main characteristics of hydrogen

\begin{tabular}{|c|c|c|c|}
\hline $\begin{array}{c}\text { Lower heating } \\
\text { value: }\end{array}$ & $\begin{array}{c}10800 \\
\mathrm{~kJ} / \mathrm{mn} 3\end{array}$ & specific heat (cp): & $\begin{array}{c}14266 \mathrm{~J} / \mathrm{kgK} \\
\left(20^{\circ} \mathrm{C}\right)\end{array}$ \\
\hline $\begin{array}{c}\text { Upper thermal } \\
\text { power: }\end{array}$ & $\begin{array}{c}12770 \\
\mathrm{~kJ} / \mathrm{mn} 3\end{array}$ & $\begin{array}{c}\text { Density (gaseous } \\
\text { state) }\end{array}$ & $0,09 \mathrm{~kg} / \mathrm{m} 3$ \\
\hline $\begin{array}{c}1 \text { normal cubic } \\
\text { meter (mn3): }\end{array}$ & $\approx 0,09 \mathrm{~kg}$ & $\begin{array}{c}\text { Density (liquid } \\
\text { state) }\end{array}$ & $\begin{array}{c}70,9 \mathrm{~kg} / \mathrm{m} 3 \\
\left(-252^{\circ} \mathrm{C}\right)\end{array}$ \\
\hline $\begin{array}{c}\text { Gaseous } \\
\text { constant: }\end{array}$ & & $4125 \mathrm{~J} / \mathrm{kgK}$ & \\
\hline
\end{tabular}

\section{Method for Hydrogen Production}

High price of hydrogen production and difficulties of its storage direct the most of the modern researches to identification of a solution that could improve its characteristics and make it more competitive in the fuel market.

The conventional technologies of hydrogen production include catalytic oxidation of carbon, production from the refinery gasses and methanol, partial oxidation of heavy hydro carbonates and coal as well as water electrolysis. According to the statistical analysis most of the hydrogen $(96 \%)$ in the world production (500 billion tones yearly) comes from the fossil fuels and spited into the primary energy sources like steam (catalytic) reforming of natural gas $(48 \%)$, partial oxidation of heavy refinery crude oil fractions $(30 \%)$, coal gasification $(18 \%)$, water electrolysis, mainly hydropower $(4 \%)$ and in the other processes. Modern technologies for hydrogen production, in order to meet anticipated needs, can be divided into three basic categories: photo-biological, photo-electrochemical and thermochemical.

Globally, hydrocarbons are used to produce $95 \%$ of hydrogen while $4 \%$ is produced by water electrolysis [2]. The commercial processes for hydrogen production which are presently used include steam reforming of natural gas, partial oxidation of heavy oil residues and electrolysis of water [3]. Already mentioned resource overall exploitation and depletion of fossil fuels encouraged the scientists to develop more sustainable processes for hydrogen production. Hydrogen can be produced in a renewable manner from lignocellulosic biomass with the use of several methods, including pyrolysis, gasification and steam reforming with special interest of biomass conversion to intermediate liquid bio-fuels (pyrolysis oil or ethanol) [3]. Some of improved ideas are to use thermochemical process of biomass gasification or process of photo-biological production, using some of the primary producers (algae).

Akkerman et al. [20] showed that biological production hydrogen can be achieved by photoautotrophic or photoheterotrophic organisms [4]. A thermochemical and photo-biological processes of production are been followed by the photo-electrochemical production, which, like photo-biological processes, use sunlight for the dissociation of water into hydrogen and oxygen. Das and Veziroglu [21] 
consider biological hydrogen production processes as more environment friendly and less energy-intensive, since most of the time photosynthetic or fermentative organisms control the process [2].

Process of hydrogen production by gasification of biomass has been developed to the extent that will in the following years enable the creation of market-competitive products. Photo-electrochemical and photo-biological productions are developing and it is anticipated that commercial applications will be available in the following decades. For example, the acid-tolerant mutant strain of Rhodovulum sulfidophilum (TH-102) with features of acid and temperature tolerance is a potential candidate for use in cost-effective hydrogen production processes, especially in those employing both dark-fermentative and photosynthetic bacteria. [5]

Researches in the field of electrolytic processes are directed towards optimizing and improving the efficiency of the process of obtaining hydrogen from water. One more solution for hydrogen production is process of electrolysis that uses Sun energy as an energy source, so called solar hydrogen. It is anticipated that, together with electricity as an important energy source for hydrogen production in the near future will be methanol, particularly applicable in the transport processes.

\section{Results}

\subsection{Hydrogen Compression}

The thermodynamics principles determine the amount of energy required to compress the gas. Physical characteristics of hydrogen make it one of the worst gases for the compression. Perfect single-stage compressor at 800 bars consumes energy, which accounts for $16 \%$ of the chemical energy that can be obtain. It is possible to use a multi-stage compressor with intercooling, which achieved $12 \%$ of the chemical energy. This is an estimation based on the actual multistage compressor running at 200 bars, but up till now this multistage compressor running at 800 bars haven't been developed. Therefore, nowadays the major technological challenge is finding out solution to compress hydrogen at 800 bars. With increment of the pressure would not be achieved significant reduction in volume, since the fact that at these high pressures hydrogen behaves less like gasses and more like a liquid.

Supporting the development of alternative technologies, many companies were involved in the research phase of the hydrogen transport. Hydrogen can be made available on-board vehicles in containers of compressed or liquefied $\mathrm{H} 2$, in metal hydrides, or by gas-on-solid adsorption. Hydrogen can also be generated on-board by reaction or decomposition of hydrogen containing species. During the last fifteen years, significant effort has been made to develop effective hydrogen storage methods, including hydrogen tank, sorbents and metal/chemical hydrides.

\subsection{Hydrogen Storage}

Development of a cost-effective way of hydrogen storage and transport from the place of production to the place of use is necessarily to be able to use hydrogen as a fuel in the transportation and electricity production. A tank for hydrogen storage in vehicles must be competitive with conventional fuel tanks by weight, volume, and size as well to have simultaneous high efficiency, safety and ability of recharge. Current researches in this field have focus in increasing the amount of energy that can be stored per unit volume or unit weight of the hydrogen tank. The volumetric density of hydrogen can be increased by liquefying it.

Current approaches for on-board hydrogen storage take into account the weight, volume, efficiency and cost of the current technologies. These approaches include compressed hydrogen gas, cryogenic and liquid hydrogen, sorbents, metal hydrides, which are categorized as 'reversible on-board' and chemical hydrides that are considered as 're-generable off-board'.

Storage of hydrogen under pressure has been successfully achieved for years using following type of tanks:

- $\quad$ Steel tanks are a good option for stationary systems where weight and size are unimportant factors. Development of the new type of combined reservoir that can store hydrogen at a pressure of 350 bars, fulfill safety standards and has the capacity of storage 10-12\% of hydrogen can be good solution. Progress has been made also in development of the reservoirs that store hydrogen at a pressure of 700 bars. They are also made less heavy combined tanks and use space better than cylindrical tanks.

- Aluminum core reinforced by glass wool

- Plastic core reinforced with glass wool

- Metal hydrides are very heavy and thus reduce the number of kilometers of distance traveled of the vehicle. Some metal hydrides have the potential for reversible onboard hydrogen storage and release hydrogen at the relatively low temperatures and pressures required for fuel cells [8]. According to mentioned authors complex metal hydrides comparing to the conventional metal hydrides offer the potential to improve gravimetric hydrogen capacity.

Modern researches have tendency to return chemical storage of hydrogen using materials made of carbon fiber, including also materials that contain carbon. These nanotubes are tiny, lightweight carbon cylinders, with a diameter of several diameters of hydrogen molecules. Hydrogen is drawn through these tubes as the liquid enters through the straw. Nanotubes allow storage of $8 \%$ hydrogen mass in the units. Scientists are still working on the development and grouping of these nanotubes, which will look like the light hydrogen sponges, and will be ideal for the vehicles tanks. Except the nanocapillaries, scientists are also developing other nanostructured materials based on the carbon. Those are used in the sphere of chemical hydrides 
that could enable its use in the cars.

Hydrogen storage in carbon single-wall nanotubes (SWNT) has become the focus of numerous research groups in the world. However, obtaining activated SWNT hydrogen storage materials with highly reproducible adsorption capacities has not yet been achieved. One reason for this may be that hydrogen storage is only optimized for a very specific and narrow distribution of SWNTs of distinct types and diameters [6].

\subsection{Hydrogen Transport}

Most of the produced hydrogen is transported on the short distance in the gaseous state, usually by pipeline. For full acceptability these technology it is crucial to solve problems related to the action of hydrogen on the piping materials and joints because, depending on the material and the pressure in the pipeline, there is a diffusion of hydrogen in the material, due to which it becomes fragile and susceptible to breakage. Also, due to the large volume of hydrogen gas, changing of use of the existing pipeline to the pipeline for hydrogen should be done due to the new requirements for dimensions of pipes and compressors.

In the transport over long distances due to lower volumes, liquid hydrogen (LH2) has advantages over hydrogen in the gaseous state. Transport of liquid hydrogen is done by ships, trucks and trains, in the tanks capacity 3,500 to $70,000 \mathrm{~kg}$. Economic studies indicate that due to the large volume of liquid gas compared to the other energy-equivalent volume of fuel and the necessary amount of insulation for tanks, liquid hydrogen transport prices will continue to be higher than the cost of other transportation fuels.

Hydrogen compressed to 800 bars occupies three times more volume than gasoline for the same energy in the car's tanks. It is necessary to reach this density so the vehicle that carries it would have sufficient amount of hydrogen. It is extremely difficult to keep hydrogen under so much pressure in the light weighted tank and catastrophic malfunction of reservoir releases energy equivalent to the explosion similar to the explosion of dynamite. Tank for hydrogen made from the very hard steel is 100 times heavier than hydrogen which it contains. A trunk or car that would use such a steel tank would be impractical because it would be heavy as the vehicle itself. Tank for storage of high pressure hydrogen which is made of carbon fiber can be a solution. Carbon fibers are material used in the manufacture of aircraft and sporting goods.

A typical four-cylinder car has a fuel tank capacity of 60 liters and can travel time of about $900 \mathrm{~km}$. Diesel engine achieve the efficiency of $35 \%$ during normal driving while the petrol engine achieves $25 \%$. Both the engine can be converted for use of hydrogen. Internal combustion engines can be used with an efficiency of $35 \%$ and a fuel cell can have $45 \%$.

Space, weight and cost of steel tanks make them impractical, meaning that any gain in energy efficiency would be disallowed by the cost of energy in the transport tank. Tanks with carbon fiber of this size and performance do not exist and they are presented just as goals in development.

Nowadays, the concept of green and smart transportation systems through hydrogen fuel is a new area to be explored and expected to become critical in especially developing countries [2].

\subsection{Hydrogen Use as a Fuel}

The reduction of harmful emissions and the production of clean electrical energy, primarily in the transport, may be achieved by using the fuel cell with hydrogen as a fuel. Fuel cells are devices that generate energy through the process of converting chemical energy of a hydrogen-rich fuel, usually the natural gas or methanol, into electricity and heat, through process of electrochemical oxidation in proton exchange membrane (PEM) of the fuel cells. For e.g. most of the produced hydrogen in US comes from a steam reforming of natural gas [11]. The main difference between fuel cells and batteries is that neither fuel nor oxidizing substances are integral parts of fuel cells, but their supply is carried by the needs and demands of consumers, while the waste products is being continuously removed.

The degree of efficiency of fuel cells is usually between 35 and $60 \%$. High cost of fuel cells and costly production technologies of hydrogen and its storage are the reason for their limited use. Until the final introduction of fuel cells and hydrogen in the energy market, as the power machines is going to be used improved engines with internal combustion, and for electivity generation in a fuel cell conventional fuels (natural gas, methanol).

The major obstacle for the development of hydrogen powered fuel cell vehicles is the lack of safe, light weight and energy efficient means for on-board hydrogen storage [8]. One of the most commonly used method for hydrogen storage in fuel cell vehicles is compressed hydrogen tanks. For example, for a 300 mile driving range, assuming 50\% fuel cell efficiency, $5.6 \mathrm{~kg}$ of usable $\mathrm{H} 2$ is required [8].

Since a fuel cell produces a voltage of about $1 \mathrm{~V}$, in order to obtain larger voltage cells are connected in series, and the heat that is released during the process can be used for different processes, that provide to the fuel cells the possibility of combining with the electricity generator and the heat in industrial or residential buildings.

Fuel cells, operating with hydrogen or hydrogen-rich fuels, have four main advantages: a higher number of cells can be grouped into packages of different sizes, they can easily be installed because practically negligible impact on the environment, have minimal maintenance requirements and they can use a variety of fuels that can be easily and quickly changed. There are also secondary benefits, such as the current-voltage reaction control, the possibility of a rapid system start; the operation does not require monitoring, etc. At the same time hydrogen is a potential clean and environmentally friendly energy carrier because the only by-product of its use in the fuel cell is 
demineralized water.

However, Martinot et al. [22] consider that, compared with other energy sources, hydrogen is recognized as the most viable, with long-term renewable alternatives to fossil fuels after solar energy. Hydrogen holds all the unique characteristics of a future dream fuel in all aspects including social, economic and environmental. It has the potential to reduce the dependence on fossil fuels in future, which can reduce the emissions associated with the transport sector [2].

\section{Discussion}

\subsection{Discussion on Economic Aspects}

Hydrogen production requires great facilities; therefore, production costs depend on the prices of basic raw materials. When hydrogen is produced in large-scale of natural gas achieved reformation efficiency is $75 \%$, which means that $3.5 \mathrm{~kg}$ of the natural gas received $1 \mathrm{~kg}$ of hydrogen. The water electrolysis has the usual efficiency of about $50 \mathrm{kWh}$ per $\mathrm{kg}$ of hydrogen. Other alternative methods, like using biomass or waste, are available but only at a non-commercial basis.

Price of the liquid hydrogen, which is in commercial use, is in a linear relation with the price of electricity. The reason for this is that electricity is a necessary source of energy for the water electrolysis. Electrolysis share in the total world production of hydrogen is $48 \%$, and until other technologies do not take a larger share in it, this dependence will be applicable.

Although the technology of production and storage of hydrogen has been established for a long time, their use is limited to the specific areas due to the hydrogen prices and problems with the storage.

There is no doubt that the national long-term infrastructure needs to be developed regarding the economical aspect of its production, marketing and investment and processing. Considering factors such as infrastructure, applied standards and quantity from the one side and cost of its storage, sustainable hydrogen economy can be discussed widely. Still, nowadays, Swesi et al. [23] highlights that introduction of a hydrogen as a fuel mainly depends on the technology of its storage [2].

\subsection{The Advantages of Hydrogen Use in Environmental Protection}

Combustion of hydrogen, in the aerobic environment under appropriate conditions in engines or gas turbines, results in very low to negligible emissions of harmful substances (Table 3). The emission of hydrocarbons and carbon monoxide are in the trace amounts, if they are even created. Emissions of nitrogen oxides increases exponentially with the temperature of combustion, but on this emission can be applied proper control of the temperature. Therefore, by hydrogen use, the emission of nitrogen oxides is reduced significantly comparing to the mineral oil and natural gas, and due to the lower combustion temperature it has advantage to the other fuels. Emissions of sulfur and particulate matter are completely avoided, except for the small amount of the train oil.

The uses of hydrogen in transportation systems with low temperature fuel cells completely eliminate almost all pollution emissions. The use of hydrogen in fuel cells at high temperature levels causing up to 100 times less pollutant emissions than conventional power plants.

Table 2. Compared characteristics of the different vehicles, tanks types and fuel types

\begin{tabular}{|c|c|c|c|c|c|}
\hline & Weight of the fuel & $\begin{array}{c}\text { Weight of the cylindrical } \\
\text { tank }\end{array}$ & $\begin{array}{c}\text { Weigh of the tanks } \\
\text { from the coal fiber }\end{array}$ & $\begin{array}{c}\text { Volume of } \\
\text { tank content }\end{array}$ & Volume of the tank \\
\hline $\begin{array}{c}\text { Average trunk with } 18 \\
\text { wheels, diesel }\end{array}$ & $533 \mathrm{~kg}$ & low & unknown & $0,637 \mathrm{~m} 3$ & $0,679 \mathrm{~m} 3$ \\
\hline Average car, gasoline & $50 \mathrm{~kg}$ & low & unknown & $0,0637 \mathrm{~m} 3$ & $0,07 \mathrm{~m} 3$ \\
\hline $\begin{array}{c}\text { Trunk (SUS) converted to } \\
\text { the hydrogen }\end{array}$ & $142 \mathrm{~kg}$ & $14197 \mathrm{~kg}$ & $3157 \mathrm{~kg}$ & $1,9 \mathrm{~m} 3$ & $4,45 \mathrm{~m} 3$ \\
\hline $\begin{array}{c}\text { Standard car converted to } \\
\text { the fuel cell }\end{array}$ & $8 \mathrm{~kg}$ & $789 \mathrm{~kg}$ & $175,5 \mathrm{~kg}$ & $0,11 \mathrm{~m} 3$ & $0,25 \mathrm{~m} 3$ \\
\hline
\end{tabular}

Table 3. Improvement of emission according to the used type of fuel [7]

\begin{tabular}{|c|c|}
\hline Fuel type & Gas Emission (g/mile) \\
\hline Current GV (Gasoline Vehicle) & 480 \\
\hline Future GV (Gasoline Vehicle) & 405 \\
\hline Current Gasoline HEV & 330 \\
\hline Future Gasoline HEV & 298 \\
\hline Future Natural Gas Distributed Hydrogen FCV & 201 \\
\hline Future Central Wind Electrolysis Hydrogen FCV & 65 \\
\hline Future Central Biomass Hydrogen FCV & 35 \\
\hline
\end{tabular}




\subsection{Negative Environmental Aspects of the Hydrogen Use}

Some American scientists argue that new technologies and new fuels can be environmentally unacceptable because of the unexpected negative impact.

For example, the broad consumption of hydrogen in initiating energy production processes, starting from the cars to the power plants, will lead to the replacement of the large amounts of hydrogen in atmosphere and stratosphere where will directly affect the ozone layer. The assumption of scientists is based on the general use of hydrogen as a fuel, and statistically speaking, about $10 \%$ of hydrogen would leaked to the warehouse, various pumps, reservoirs, during the breakdowns, which would cause perceived problems. The conclusion is that the use of hydrogen by itself will not affect the pollution emission decrement, but still environmental state will depend on the human factor.

\section{Conclusions}

Rapid decrement of fossil fuels together with an increasing environmental threats and a constant atmospheric pollution during last century, resulted in encouraging researches of a new energy source or fuel. According to hydrogen characteristics, primarily the availability, it is emerging as the only candidate to take primacy in this field.

Although the technology of production and storage of hydrogen has been established for a long time, their use is limited to the specific areas due to the hydrogen prices and storage. Most of the current researches are focused on finding cost-effective ways of hydrogen production and storage that will made it competitive in the fuel market. The utilization degrees of the most advanced technologies of hydrogen production (photo - biological, photo electrochemical, thermo chemical) still are not acceptable. Plans are that in the short-term, in the market technologies of hydrogen production take leading position production from the biomass, which is followed by the so-called solar hydrogen.

Together with the development of the conventional method of hydrogen storage (gaseous and liquid state) are developing and advanced technologies of its storage, and seems that the best perspective for future implementation have metal hydrides or the latest technology of carbon nanocapillaries and glass microspheres.

Introduction of hydrogen in the area of transport, as a replacement fuel in the internal combustion engines, and as a fuel for the fuel cells have been noticed as well. Fuel cell technology has been developed sufficiently to be introduced into the transport systems (vehicles) as well as for commercial use, but their widespread application is again limited by the price of hydrogen. It is anticipated that in the transitional period, while the cost of production and storage of hydrogen, as well as the cost of fuel cells have reached an acceptable height, will be used upgraded engines with internal combustion engines with hybrid fuel (fossil fuel with a certain proportion of hydrogen in the mixture), or methanol or natural gas in the fuel cell.

\section{REFERENCES}

[1] A. Ajanovic, "Renewable fuels - A comparative assessment from economic, energetic and ecological point-of-view up to 2050 in EU-countries," Renew. Energy, vol. 60, pp. 733-738, 2013.

[2] A. Ahmed, A. Q. Al-Amin, A. F. Ambrose, and R. Saidur, "Hydrogen fuel and transport system: A sustainable and environmental future," Int. J. Hydrogen Energy, vol. 41, no. 3, pp. 1369-1380, 2016.

[3] A. N. Fatsikostas, D. I. Kondarides, and X. E. Verykios, "Production of hydrogen for fuel cells by reformation of biomass-derived ethanol," Catal. Today, vol. 75, no. 1-4, pp. 145-155, 2002.

[4] M. Rabbani, I. Dincer, and G. F. Naterer, "Experimental investigation of hydrogen production in a photo-electrochemical chloralkali processes reactor," Int. J. Hydrogen Energy, vol. 41, no. 19, pp. 7766-7781, 2016.

[5] J. Cai and G. Wang, "Photo-biological hydrogen production by an acid tolerant mutant of Rhodovulum sulfidophilum P5 generated by transposon mutagenesis," Bioresour. Technol., vol. 154, pp. 254-259, 2014.

[6] A. C. Dillon, K. E. H. Gilbert, P. A.Parilla, J. L. Alleman, G. L. Hornyak, K. M ,Jones, \& M. J. Heben. Hydrogen storage in carbon single-wall nanotubes, FY 2003 Progress Report Hydrogen, Fuel Cells, and Infrastructure Technologies, 1-18, 2003.

[7] Fuel cell electric vehicles, Online Available from: http://www.fuelcells.org

[8] H. T. Hwang, \& A. Varma. Hydrogen storage for fuel cell vehicles, Current Opinion in Chemical Engineering, Vol.5, 42-48, 2014.

[9] H. Milosevic, S. Stevovic, and D. Petkovic. Numerical simulation of interaction during top blow in a steel-making converter, International Journal of Heat and Mass Transfer, 54 (19), 4275-79, 2011.

[10] H. Milosevic, N.Ahmetovic Geydarov, Y. Nikolaevich, S. Stevovic. Model of incompressible viscous fluid flow driven by pressure difference in a given channel, International Journal of Heat and Mass Transfer, Vol. 62, 242-46, 2013.

[11] National Renewable Energy Laboratory. Hydrogen \& Fuel cell research. Online Available from: http://www.nrel.gov/hydrogen

[12] Office of Energy \& Renewable Energy. Fuel Cell technology. Online Available from: http://www.eere.energy.gov

[13] S. M. Stevović, H. Milošević, I. Stevović, S. Hadrović. Sustainable management of water resources in Prokletije region, Industrija, Vol.42 (1), 47-61, 2014. 
[14] S. Stevovi, and D. Calic-Dragosavac. Environmental study of heavy metals influence on soil and Tansy (Tanacetum vulgare L.), African Journal of Biotechnology, Vol. 9 (16), 2392-400, 2010.

[15] S. Stevovic, N. Devrnja, and D. Calic-Dragosavac. Environmental impact quantification and correlation between site location and contents and structure of Tansy, African Journal of Biotechnology, Vol.10 (26), 5075-83, 2013.

[16] S. Stevovic, M. Miloradovic, and I. Stevovic. Management of environmental quality and Kostolac mine areas natural resources usage, Management of Environmental Quality: An International Journal, 25 (3), 285-300, 2014.

[17] Sudarević D., Kozić A. Uticaj alternativnih goriva u motorima SUS na očuvanje životne sredine, Festival kvaliteta-Jedanaesta nacionalna konferencija o kvalitetu, 202-210, 2005.

[18] The Linde group, Hydrogen: From well to wheel. Online Available from: http://www.linde-gas.com
[19] WOW Alien Signal Higgs Boson Mu2e Electron UFO Research, Online Available: http://alienspacesciencenews. wordpress.com/2013/10/14/line-22-7b97z47b-helmholtz-coil s-laplace-spherical-harmonics-higgs-formula-5g-wow-seti.

[20] I. Akkerman, M. Janssen, Jorge Rocha, Ren? e H. Wijffels. Photobiological hydrogen production: photochemical efficiency and bioreactor design, International Journal of Hydrogen Energy, 200, Volume 27, Issues 11e12, Pages $1195 \mathrm{e} 1208$

[21] Das D, Veziroglu TN. Hydrogen production by biological processes: a survey of literature. Int J Hydrogen Energy 2001;26(1):13e28.

[22] Martinot E, Dienst C, Weiliang L, Qimin C. Renewable energy futures: targets, scenarios, and pathways. Annu Rev Environ Resour 2007; 32:205e39.

[23] Swesi Y, Ronze D, Pitault I, Dittmeyer R, Heurtaux F. Purification process for chemical storage of hydrogen for fuel cell vehicles applications. Int J Hydrogen Energy 2007; 32(18):5059e66. 